\title{
COMMENT
}

\section{IMPLEMENTING POLICY OBJECTIVES IN THE TAXATION OF DEFERRED COMPENSATION ARRANGEMENTS}

Over the years, the nonqualified deferred compensation arrangement has become a much-used tool in the hands of the executive and his tax planner. ${ }^{1}$ By resort to such an arrangement, the executive can delay payment of part or all of his current compensation until his income and tax brackets are lower. The highly paid corporate executive thereby incurs a smaller tax and thus realizes a tax savings at the expense of the rest of the taxpaying public. Yet a fundamental assumption of tax reform generally, as well as the underlying principle of progressive taxation itself, is that wealth should be redistributed downward. ${ }^{2}$

THE FOLLOWING CITATIONS WILL BE USED IN THIS NOTE:

Senate Comm. on Finance, Report on the Revenue Act of 1978, H.R. 13511, S. Rep. No. 1263, 95th Cong., 2d Sess., reprinted in [1978] 9 FED. TAXES (P-H) I] 60,611, Rep. Bull. 43, section 2 (separate booklet) [hereinafter cited as S. REP. ON H.R. 13511];

House Comm. on Ways and Means, Report on the Revenue ACt of 1978, H.R. 13511, H.R. REP. No. 1445, 95th Cong., 2d Sess., reprinted in [1978] 9 FED. TAXES (P-H) I 60,489, Rep. Bull. 35, section 2 (separate booklet) [hereinafter cited as H.R. REP. ON H.R. 13511];

Senate Committee on Finance, Report on Tax Reform Act of 1969, S. Rep. No. 552, 91st Cong., 1st Sess., reprinted in [1969] U.S. CoDE CoNG. \& AD. NEws 2027 [hereinafter cited as 1969 S. REP.];

G. Washington \& V. Rothschild, Compensating the Corporate Executive (3d ed. 1962) [hereinafter cited as WASHINGTON \& RoTHSCHILD];

McDonald, Deferred Compensation: Conceptual Astigmatism, 24 TAX L. Rev. 201 (1969) [hereinafter cited as McDonald];

Metzer, Constructive Receipl, Economic Benefit and Assignment of Income: A Case Study in Deferred Compensation, 29 TAX L. REv. 524 (1973) [hereinafter cited as Metzer].

1. See generally $T$. Patten, Pay: Employee Compensation and InCentive Plans 504-06 (1977); 1 Washington \& Rothschild 106-64; Lasser \& Rothschild, Deferred Compensation for Executives, 33 HaRv. Bus. Rev. 89 (1955).

2. See H.R. Rep. No. 413, 91 lst Cong., 1st Sess. 8-12 (1969), reprinted in [1969] U.S. Code Cong. \& AD. News 1645, 1653-56. "Tax reform is necessary both to be sure that those with substantially the same incomes are paying substantially the same tax and also [sic] to make sure that the graduated income tax structure is working fairly as between different income levels." H.R. REP. No. 413, supra at 10, reprinted in [1969] U.S. CoDE CoNG. \& AD. News 1645, 1654. The 1969 House report also discussed problems of taxpayer morale, noting that "[t]he fact that 
The deferred compensation plan ideally is intended as a device for retirement planning; however, in the context of the nonqualified plan, the primary goal is often tax avoidance. ${ }^{3}$ The nonqualified plan exists essentially for the employer who wishes to favor his top executives and for the key employee whose compensation goals exceed those secured by the qualified plan. ${ }^{4}$ While the availability of nonqualified deferred compensation arrangements may be a desirable thing from certain standpoints, there are policy considerations that would indicate that a restrictive treatment of such arrangements is in order.

In February 1978, a treasury regulation was proposed that would have had a substantial effect on the future availability of executive deferred compensation arrangements. ${ }^{5}$ The proposed regulation provided that any amount of compensation income deferred at the option of the individual entitled to receive it was to be reportable in the year in which such amount would have been received but for the agreement stipulating a later date for payment. ${ }^{6}$ Because the proposed regulation would have eliminated a great many executive deferred compensation plans, reaction on the part of the business community was predictably adverse. When the Treasury Department sought legislative authority for the proposed change, Congress acted on behalf of the business community to defeat the proposal outright and without compromise. ${ }^{7}$

present law permits a small minority of high-income individuals to escape tax on a large proportion of their income has seriously undermined the feeling of taxpayers that others are paying their fair share of the tax burden." Id. That these problems are still with us today is evidenced by the results of a recent Roper survey released in July, 1978. The survey indicates "that the American public considers tax reform the third most pressing national problem ranking behind only controlling inflation and lowering the crime rate. And significantly, tax reform to the Roper respondents is equated much more frequently with tax fairness [than] with tax reductions." Revenue Act of 1978: Hearings on H.R. 13511 Before the Senate Comm. on Finance, 95th Cong., 2d Sess. 3 (1978) (statement of Sec'y of the Treas. Michael Blumenthal), reprinted in Daily Tax Rep. (BNA) J-1 (Aug. 17, 1978). As one author has noted: "Though the debate over tax reform deals extensively with economic policy considerations, the movement's 'gut issue' is equity in taxation, or more specifically, redistribution of income to provide greater equality in after-tax income." $R$. FREEman, Tax Loopholes 36 (1973). See 1 Washington \& Rothschild 161-62; Eisenstein, $A$ Case of Deferred Compensation, 4 TAX L. Rev. 391, 400 (1949). For a further discussion of this and related issues, see text accompanying note 86 infra.

3. Commentators often talk in terms of providing incentives for the executive. However, it is the tax saving made possible by the deferral arrangement which is often the most significant component of that incentive. See T. PATTEN, supra note 1, at 504-05; 1 WASHINGTON \& RothsCHILD 107, 163; Colby, Employee Compensation Techniques after the 1976 TRA, 36 N.Y.U. INST. FED. TAX. 671-72 (1978); Lasser \& Rothschild, supra note 1, at 89, 95. See also Kraus, The Devaluation of the American Executive, 54 HARV. BuS. REv. 84 (1976).

4. See text accompanying notes 19-27 infra.

5. Proposed Treas. Reg. § 1.61-16, 43 Fed. Reg. 4638 (1978).

6. Id. See note 100 infra.

7. Under provisions of the Revenue Act of 1978, the law in respect to deferred compensation plans must be administered "in accordance with the principles set forth in regulations, rul- 
Thus, the underlying policy considerations that gave rise to the controversy have yet to be addressed effectively.

This Comment proposes a compromise which is intended to serve as a vehicle for at least partial implementation of policy objectives in the area of deferred compensation arrangements, while avoiding the practical and political difficulties presented by the proposed regulation. Briefly stated, the proposal advocated by this Comment would impose an overriding requirement of forfeitability on all nonqualified deferred compensation plans. Present law distinguishes between funded and unfunded deferred compensation arrangements, requiring forfeitability as a condition precedent to tax deferral only in the case of funded plans. ${ }^{8}$ This Comment rejects this distinction on theoretical grounds because by the terms of both the funded and the unfunded nonqualified deferred compensation arrangement, the employee-obligee is the recipient of a current economic benefit as soon as his rights to deferred income become nonforfeitable. As a practical matter, a forfeitability requirement would operate to impose greater restrictions on the availability of the nonqualified arrangement while at the same time preserving it as a viable alternative to the qualified plan.

\section{The Current Tax Treatment of Nonqualified Deferred Compensation Plans}

\section{A. Historical Background.}

On June 1, 1937, President Roosevelt addressed Congress about the need for reform of the exemption for pension, profit-sharing and bonus plans. ${ }^{9}$ His message referred to a letter from the Secretary of the Treasury which observed that the exemption "ha[d] been twisted into a means of tax avoidance by the creation of pension trusts which include as beneficiaries only small groups of officers and directors who are in the high income tax brackets." 10 The situation described by the Secre-

ings, and judicial decisions relating to deferred compensation which were in effect on February 1 , 1978." Revenue Act of 1978, Pub. L. No. 95-600, § 132, 92 Stat. 2782. It is intended that these principles are to be determined without regard to the proposed deferred compensation regulation under section 61 of the Code which was published in the Federal Register, 43 Fed. Reg. 4638 (1978). S. REP. ON H.R. 13511, at 72.

8. See notes $42-48$ infra and accompanying text.

9. 81 ConG. ReC. 5125 (1937). The prevailing revenue laws exempted from income tax a trust created by an employer as part of a stock-bonus, profit-sharing or pension plan for the exclusive benefit of some or all of his employees and specified that a distributee was to be taxed upon amounts actually distributed or made available to him only to the extent that distributions exceeded his contributions. Rev. Act of 1926, ch. 27, § 219(f), 44 Stat. 9; Rev. Act of 1921, ch. 136, $\S 219(\mathfrak{f}), 42$ Stat. 247.

10. 81 CoNG. Rec. 5125 (1937). 
tary had resulted from special tax legislation granting favorable treatment to pension plans. Such legislation, enacted as early as $1926,{ }^{11}$ permitted employers to take advantage of its provisions primarily for the benefit of key employees. ${ }^{12}$ The resulting pension arrangements were in direct contravention of what the Treasury Department regarded as the design and purpose of pension plans, namely, "to enable all or a large percentage of the total number of the employer's clerks and workmen (as distinguished from persons in positions of authority) to . . . provide for [themselves] upon their retirement from employment." ${ }^{13}$ It was in response to these abuses that the present tax treatment of pension benefits began to emerge. ${ }^{14}$

\section{B. The Trend Away from Qualified Plans.}

The provisions of the 1939 Internal Revenue Code with respect to pension, profit-sharing and bonus plans have been significantly expanded under the present Code. ${ }^{15}$ Under section 401(a) of the Code, stringent requirements must be satisfied in order for a trust forming part of a stock-bonus, pension or profit-sharing plan to qualify for maximum tax advantages. Although these requirements often discourage participation on the part of employers - especially those concerned with the interests of the high-level executive ${ }^{16}$ - qualified deferred compensation plans offer several tax benefits. Chief among these are the capital gains treatment afforded the employee with respect to distributions made to him under a qualified trust or annuity plan, ${ }^{17}$ and the

11. Rev. Act of 1926 , ch. $27, \$ 219(f), 44$ Stat. 9.

12. The tax statute required only that a plan be "for the exclusive benefit of some or all of the employees." Id.

13. Treas. Reg. 101, art. 165-1 (1939), quoted in 2 WASHINGTON \& RothSCHILD 661.

14. The first significant changes were introduced by the Revenue Act of 1942, which established nondiscrimination requirements for the first time. Rev. Act of 1942, ch. 619, $\$ 162,56$ Stat. 798 (amending I.R.C. of 1939, $\S 322(\mathrm{~b})(2), 23(\mathrm{p})$, I65(a)-(c), now I.R.C. of 1954 Subchapter D). See Goodfellow, The Tax Consequences of Pension Trusts and Employer Purchased Annuities, 39 CAL. L. REv. 204 (1951); Goodman, Legislative Development of the Federal Tax Treatment of Pension and Profit-Sharing Plans, 49 TAXES 226 (1971).

15. I.R.C. $\$ \S 401-15,421-26$.

16. For a plan to qualify, it must be offered on a nondiscriminatory basis. I.R.C. $\$ 401$ (a)(4). As one commentator has stated: "[I]n many cases the practical result of the nondiscrimination requirement necessitates inclusion in the plan of so large a group of employees as to render it prohibitively expensive if appreciable benefits to executives are contemplated." Lasser \& Rothschild, supra note 1, at 95 (emphasis added). This result should not be regarded as anomalous, however, since just such a result was specifically intended by Congress. It is the common worker who is the intended beneficiary under the qualified plan. See text accompanying note 13 supra. In the words of political theorist John Rawls, the qualified plan works by design, "to the greatest benefit of the least advantaged." J. RAwLS, A THEORY OF JUSTICE 302 (1973).

17. I.R.C. $\$ 402(\mathrm{a})(2)$ (relating to taxability of beneficiary of employees' trust); $i d . \S 403(\mathrm{a})(2)$ (relating to taxation of employee annuities). 
availability of an immediate deduction to the employer for contributions paid into the plan. ${ }^{18}$

In order for a plan to qualify, contributions or benefits under the plan may not discriminate in favor of highly compensated executives, officers or shareholder-employees. ${ }^{19}$ Moreover, the plan must be maintained for the exclusive benefit of the employees ${ }^{20}$ and it must satisfy minimum participation, ${ }^{21}$ vesting ${ }^{22}$ and funding standards ${ }^{23}$ added to the Code by provisions of the Employee Retirement Income Security Act (ERISA) ${ }^{24}$ Not surprisingly, perhaps, the Code provisions added by ERISA are largely responsible for a growing trend away from qualified plans and toward executive nonqualified deferred compensation arrangements. ${ }^{25}$

The changes introduced by ERISA have made the qualified plan particularly burdensome from the employer's perspective ${ }^{26}$ and have operated as a disincentive to the employer to qualify under the Code by offering deferred compensation on a nondiscriminatory basis. This is especially so where the employer was primarily interested in benefiting his key employees in the first place. Compounding this disincentive is the fact that if the employer chooses to satisfy the requirements of the Code by offering a broadly based qualified plan, he will discover that the limitations on contributions and benefits under the qualified plan $^{27}$ render it inadequate to serve the typical corporate executive's compensation goals.

ERISA has had a substantial impact on many nonqualified plans as well. Any employee-benefit plan-whether or not qualified under the Code-that is established or maintained by an employer engaged in

18. Id. $\S 404(\mathrm{a})(1)$.

19. I.R.C. $\$ 401(a)(4)$ provides as follows:

(a) Requirements for qualification.-A trust created or organized in the United States and forming part of a stock bonus, pension, or profit-sharing plan of an employer for the exclusive benefit of his employees or their beneficiaries shall constitute a qualified trust under this section-

...

(4) If the contributions or the benefits provided under the plan do not discriminate in favor of employees who are-

20. Id. \& 401(a)(2).

(A) officers,

(B) shareholders, or

(C) highly compensated.

21. Id. $\S 410$.

22. Id. $\$ 411$.

23. Id. $\S 412$.

24. Employee Retirement Income Security Act of 1974, Pub. L. No. 93-406, \$\& 1011, 1012(a), 1013(a), 1014, 1015 and 2004(a), 88 Stat. 829 (adding $\$ \S 410-415$ respectively to the Code).

25. Colby, supra note 3 , at $682-83$.

26. $I d$.

27. I.R.C. $\S 415$. 
or affecting interstate commerce will be subject to the participation, vesting, funding and fiduciary responsibility provisions generally applicable to qualified plans, unless the plan falls within a specific exemption from the provisions of ERISA. ${ }^{28}$ Two exemptions available to nonqualified plans are especially significant. One type of exempt arrangement is an "excess benefit plan" 29 that is defined as one maintained "solely for the purpose of providing benefits for certain employees in excess of the limitations on contributions and benefits imposed by section $415 \ldots . .30$ A second exemption is provided for "a plan which is unfunded and is maintained by an employer primarily for the purpose of providing deferred compensation for a select group of management or highly compensated employees . . . ."31

Like qualified plans, those nonqualified plans that are not exempt from ERISA have become less desirable. On the other hand, those nonqualified plans which are exempted from the provisions of ERISA have assumed a new significance and value to those who are eligible to participate in such arrangements. The result is that ERISA has had the effect of discouraging participation in qualified plans generally and of indirectly encouraging the utilization of executive deferred compensation arrangements. It is the growing utilization of the nonqualified plan in this context that prompted the drafting of proposed regulation section $1.61-16 .^{32}$

\section{The Nature of the Nonqualified Plan.}

1. The Advantages of the Nonqualified Plan. Although nonqualified plans lack many of the advantages associated with qualified plans, ${ }^{33}$ one significant advantage remains-the deferral of compensation until income and tax brackets are lower. There are other advantages associated with the nonqualified plan; however, these advantages ultimately are a function of the executive's ability to avoid current tax liability for some of his currently earned income. For example, one commentator notes that an important objective of compensation defer-

28. Employee Retirement Income Security Act of 1974, Pub. L. No. 93-406, $\S \S 201,301$, and 401, 88 Stat. 829 (coverage of participation and vesting requirements funding, requirements, and fiduciary responsibility provisions, respectively).

29. Id. $\S \S 4(\mathrm{~b}), 201(7), 301(\mathrm{a})(9)$.

30. Id. §3(36).

31. Id. $\S \S 201(2), 301(\mathrm{a})(3), 401(\mathrm{a})(1)$.

32. According to IRS officials, Proposed Regulation section 1.61-16 was specifically intended to check this development by eliminating elective deferrals. Inasmuch as it is almost exclusively executives who are in a position to elect the form which their compensation will take, the proposed regulation would have operated primarily to eliminate executive deferred compensation arrangements. Telephone interviews with IRS officials (Sept. 12, 1978).

33. See text accompanying notes 17-18 supra. 
ral for the executive is estate planning. ${ }^{34} \mathrm{He}$ adds, however, that "[t]o a very important extent, although it may seem flippant to put it this way, estate planning amounts to planning how to disinherit the Internal Revenue Service (but in a lawful way)." 35 Others similarly observe that "through such an arrangement, the executive is endeavoring to have the company provide him with an income after retirement, not on the relatively modest basis available to employees generally under a qualified pension program, but on the basis of his highest earnings during employment." 36 Thus, although there is an element of estate planning served by the executive deferred compensation arrangement in many cases, there is nonetheless an overriding concern that income be maximized in later years by this method of tax avoidance which "paternalistically guarantee[s] the executive the estate which others must create for themselves through their own thrift."37

Other advantages often associated with the nonqualified plan include its work incentive value; ${ }^{38}$ the means it provides for assuring the executive a minimum flow of income and for reducing fluctuations in his earnings; ${ }^{39}$ and the manner in which it operates to restore pay differentials between higher and lower paid personnel. ${ }^{40}$ All of these advantages, however, are a function of tax avoidance and foster goals that are contrary to sound tax policy. As one commentator has remarked, "[t] he art of tax avoidance . . . is to approximate a good deal of the clearly taxable transaction without incurring a good deal of the tax consequences." ${ }^{\prime 1}$ If the practice cannot be eliminated, it should at least be sharply limited. However, current law restricts the availability of types of nonqualified plans with an uneven hand.

2. Distinguishing Funded from Unfunded Plans. When compensation is deferred under a nonqualified funded plan, the employer generally will deposit funds into an employee trust or purchase an employee annuity. Both the trust and annuity forms of a funded plan are covered under the Code $\mathrm{e}^{42}$ and the rules under which they operate are relatively straightforward. The employer's contributions to the fund are not includible in the employee's gross income until such time as his rights in the trust or annuity are transferable or no longer subject

\footnotetext{
34. T. Patten, supra note 1 , at 483.

35. Id. 485.

36. 1 WASHINGTON \& ROTHSCHILD 162.

37. Id. 161 .

38. Id. 163; Lasser \& Rothschild, supra note 1, at 98.

39. I WASHINGTON \& ROTHSCHILD 163; Lasser \& Rothschild, supra note 1, at 97.

40. 1 Washington \& Rothschild 163. See generally Kraus, supra note 3.

41. Eisenstein, supra note 2 , at 400 .

42. I.R.C. $\S \S 402(\mathrm{~b}), 403$ (c) (covering trusts and annuities, respectively).
} 
to a substantial risk of forfeiture. ${ }^{43}$ The Code provides that the rights of a person in property are subject to a substantial risk of forfeiture if the rights to full enjoyment of such property are "conditioned upon the future performance of substantial services by any individual." 44 In the usual case, then, the employee's rights in the deferred payments are conditioned upon his remaining in the company's employ for a stated number of years. Of course, there are other contingencies that may be tied to the right to receive payments that will equally satisfy the forfeiture requirements for purposes of deferral. While the new treasury regulations provide a number of illustrations that are useful in determining under what circumstances the possibility of a forfeiture will be regarded as substantial, ${ }^{45}$ in the last analysis, whether a risk of forfeiture is substantial will depend upon the facts and circumstances surrounding the arrangement. ${ }^{46}$

In contrast to the funded plan, the unfunded deferred compensation arrangement ${ }^{47}$ need not be subject to the possibility of forfeiture nor to any other substantial limitations on the right to receive payments. Therefore, the employer and employee need only agree to defer payment of some part of the employee's current salary or bonus until a stipulated future date. The unconditional agreement itself suffices to prevent the current taxation of deferred compensation. No funds are set aside by the employer for purposes of the arrangement. Rather, the employer is under a simple contractual obligation to make payments at a later date. ${ }^{48}$

Different legal doctrines govern the operation of the funded and

43. Id. The forfeitability requirement under these provisions of the Code is cross-referenced to the forfeitability requirement prescribed in I.R.C. $\$ 83$ (a). See text accompanying notes 51-57 infra.

44. I.R.C. $\$ 83(\mathrm{c})(1)$. With regard to the requirement that contributions made to the trust be nontransferable, the Code provides in circular fashion that " $[t]$ he rights of a person in property are transferable only if the rights in such property of any transferee are not subject to a substantial risk of forfeiture." $I d$. $\S 83$ (c)(2). For the text of section 83, accompanied by the Senate Committee report, S. REP. No. 552, 9 1st Cong., 1st Sess. 119 (1969), and the Conference Committee report, H.R. Rep. No. 782, 91 st Cong., 1st Sess. 303 (1969), see 6 J. Rabkin \& M. Johnson, Federal InCOME, GifT AND Estate TAXATION 1270-78 (Supp. 1976).

45. Treas. Reg. $\$ 1.83-3(c)(2)$ (1978). For example, the regulation provides that when an employee receives property from an employer subject to a requirement that it be returned if the total earnings of the employer do not increase, such property is subject to a substantial risk of forfeiture. On the other hand, requirements that the property be returned to the employer if the employee is discharged for cause or for committing a crime will not be considered to result in a substantial risk of forfeiture.

46. Treas. Reg. \$ 1.83-3(c)(1) (1978).

47. The unfunded arrangement is governed primarily by Treas. Reg. $\S 1.451-2$ (1971) and by general tax principles discussed in text accompanying notes 59-62 infra.

48. See notes 67-69 infra and accompanying text. Although there is no immediately apparent benefit to the employer, there are advantages to the arrangement from his perspective as well. 
unfunded nonqualified deferred compensation arrangement. The unfunded arrangement raises issues related to constructive receipt, while the taxation of its funded counterpart represents an application of the economic benefit rule.

\section{Rules Governing the Nonqualified Plan-Economic Benefit and Constructive Receipt.}

Although as a general rule cash method taxpayers report income for the year in which they actually receive it in cash or its equivalent, ${ }^{49}$ in certain instances they may be held in constructive receipt of income which is not presently reduced to possession. Where constructive receipt is found, the income is reportable on a current basis. ${ }^{50}$ A second generally accepted principle - the cash equivalent or economic benefit rule-is that a taxpayer has currently taxable income when he receives the equivalent of cash in the form of an economic benefit. ${ }^{51}$ Inasmuch as either of these findings effectively would defeat the purposes served by a deferred compensation arrangement, the tax planner's first concern is to structure the deferred compensation plan so as to avoid the application of either rule.

1. The Funded Plan. The funded nonqualified deferred compensation arrangement is governed by sections 402(b) and 403(c) of the Code. These provisions represent a codification of the economic benefit rule as it relates to nonqualified plans. ${ }^{52}$ The theory of taxation embodied in these sections is that when the amount placed in trust for an employee, or expended on his behalf to purchase an annuity, is nonforfeitable at the time it is contributed, the employee has received an economic benefit that is taxable on a current basis. Under present law, these provisions have been cross-referenced to section 83 of the Code. ${ }^{53}$

Section 83 represents both a codification and an expansion of the

Aside from the benefit flowing to the employer from the incentive which such plans serve to instill in the employee, see authorities cited in note 3 supra, there are indirect pecuniary benefits. Payment later for services rendered now obviously has the effect of increasing the employer's current cash flow. ...

... Under accepted present value analysis, a dollar in an employer's pocket today is worth more than a dollar which must be paid at some distant date, especially if the employer can earn a rate of return on this dollar which is higher than any inflation factor it must add to the deferred amount.

Greene, Compensating the Executive in Cash: Payment Now or Payment Later, 30 Major TAX PLAN. 193, 203 (1978). "[T] he employer's increased cash flow from deferral will be available to finance not only current operating needs but also expansion." Id. 206.

49. I.R.C. $\$ 451$.

50. Treas. Reg. \& 1.451-2 (1971).

51. Id. $\S \S 1.61-2(\mathrm{~d})(1978), 1.446-1(\mathrm{a})(3)(1973), 1.446-1(\mathrm{c})(1)(\mathrm{i})(1973)$.

52. See McDonald 204.

53. I.R.C. $\$ \$ 402(b), 403(c)$. 
common law economic benefit rule as it applies to transfers of property in connection with the performance of services. In essence, section 83 provides that in any case where, in payment for the performance of services, property is transferred to any person other than the one performing the services, the taxpayer who performs the services must include the fair market value of such property in his gross income to the extent that it exceeds the amount (if any) paid for the property. ${ }^{54}$ However, the property is not taxable as income unless it is transferable or nonforfeitable. ${ }^{55}$ In the context of funded nonqualified deferred compensation arrangements covered under the provisions of section 402(b) and 403(c), the value of the employee's interest in the trust or annuity is substituted for the fair market value of the property for purposes of applying section 83 , that is, the contributions made by the employer will not be taxable to the employee until his interest in such deferred amounts is nonforfeitable. ${ }^{56}$ Regardless of the context in which it is applied, the theory is that a taxpayer does not receive a valuable economic benefit until his interest is no longer subject to a substantial risk of forfeiture. ${ }^{57}$

2. The Unfunded Plan. Under present law, "[a] mere promise to pay, not represented by a note or secured in any way, is not regarded as a receipt of income within the intendment of the cash receipts and disbursements method." 58 Thus, the unfunded deferred compensation arrangement-which is essentially an unsecured promise to pay money in the future-is not governed by the economic benefit rule. Under current law the promisee in such an instance is not in actual receipt of the money. He may yet be in constructive receipt of deferred compensation.

The doctrine of constructive receipt is purely a "creature of the Regulations; they prescribe the conditions which make the doctrine applicable." 59 Although the first formal incarnation of the concept dates as far back as 1919,60 it remains substantially unchanged to this day. The concept is presently embodied in section 1.451-2 of the Regulations which provides as follows:

(a) General Rule. Income although not actually reduced to a taxpayer's possession is constructively received by him in the taxable year during which it is credited to his account, set apart for him, or

\footnotetext{
54. Id. $\$ 83(\mathrm{a})$.

55. Id.

56. I.R.C. $\$ \S 402($ b) and $403($ c), respectively.

57. See Treas. Reg. $\$ 1.83$ (1978).

58. Rev. Rul. 60-31, 1960-1 C.B. 174, 177.

59. Hyland v. Commissioner, 175 F.2d 422, 423 (2d Cir. 1949).

60. Treas. Reg. 45, art. 53, T.D. 2831, 1919.
} 
otherwise made available so that he may draw upon it at any time, or so that he could have drawn upon it during the taxable year if notice of intention to withdraw had been given. However, income is not constructively received if the taxpayer's control of its receipt is subject to substantial limitations or restrictions. ${ }^{61}$

Thus, as a matter of strategy, if the deferred compensation plan or arrangement is to achieve its ends, some substantial limitation must be placed on the taxpayer's right to receive the deferred income.

There are a number of factors that contribute to a finding of constructive receipt. ${ }^{62}$ If an agreement to defer compensation has the earmarks of a sham executed for the purpose of selecting the year in which to report available income, the taxpayer will be deemed to be in constructive receipt of deferred amounts. ${ }^{63}$ Accordingly, constructive receipt is likely to be found if an agreement to defer payment is entered into after the compensation is earned and payable. ${ }^{64}$ On the other hand, a bona fide agreement to defer the payment of compensation which is executed prior to the rendition of services will operate to avoid a finding of constructive receipt. ${ }^{65}$ Because of the prior contract, the compensation is not available to the taxpayer when earned and remains unavailable until the date stipulated by the parties. ${ }^{66}$ Indeed, before that time, the taxpayer has no legal right to require payment. ${ }^{67}$ In addition, a taxpayer may even accomplish deferral of income already earned through a novation of his employment contract. The only requirement is that the new agreement be executed prior to the date on

61. Treas. Reg. $\S 1.451-2$ (1971). It has been suggested that

[t] he doctrine applies only where the taxpayer's control of the item credited is unrestricted. Thus, a sum is not constructively received if it is only conditionally credited; or if it is indefinite in amount; or if the payor has no funds with which to pay the credits; or if it is subject to any other substantial limitation.

Commentary to Treas. Reg. § 1.451-2 (1971), [1978] FED. TAXES (P-H) I 20,152.

62. A detailed discussion of the doctrine of constructive receipt is beyond the scope of this Comment. For comprehensive discussions of the topic, see 1 WASHINGTON \& RothsCHILD 10636; Fischer, Executive Compensation Today, 53 TAXES 886 (1975); Jones, Comparative Analysis of Qualified and Deferred Compensation Plans, 32 N.Y.U. INST. FED. TAX. 957 (1974); Knight, Income Tax Consequences of Nonqualified Deferred Compensation, A Recapitulation, 21 TAX LAW. 163 (1967); McDonald; Metzer, Rice, The New Tax Policy on Deferred Compensation, 59 Mich. L. REv. 381 (1961).

63. Joseph Frank, 22 T.C. 945 (1954); Hamilton Nat'l Bank, 29 B.T.A. 63 (1933).

64. Oliver G. Willits, 50 T.C. 602 (1968); Behlmer D. Laramy, 25 T.C.M. 809 (1966). See Knight, supra note 62, at 171-73.

65. Ray S. Robinson, 44 T.C. 20 (1965), acq. 1970-2 C.B. xxi; Rev. Rul. 69-650, 1969-2 C.B. 106; Rev. Rul. 68-86, 1968-1 C.B. 184; Rev. Rul. 60-31 Exs. 1, 2 and 3, 1960-1 C.B. 174. See Oliver v. United States, 193 F. Supp. 930 (E.D. Ark. 1961); J.D. Amend, 13 T.C. 178 (1949), acq. 1950-1 C.B. 1. See generally Ballard, Nonqualified Deferred Compensation: Elective Plans and Other Developments, 25 TAX LAw. 299, $306-08$ (1972); Metzer 538-40.

66. See James Gould Cozzens, 19 T.C. 663 (1953); Clifton B. Russel, 5 T.C. 974 (1945).

67. This is true as a matter of simple contract law. See Glenn v. Penn, 250 F.2d 507 (6th Cir. 1958) (dictum). 
which the amounts earned are determinable or become due. ${ }^{68}$

3. Revenue Ruling 60-31. Although the principles described above have been relied upon by courts for some time, ${ }^{69}$ it was not until 1960 that they were verified by the IRS in certain important respects. Prior to 1960, the Service's refusal to issue rulings regarding nonqualified deferral arrangements-despite numerous requests-had created considerable uncertainty among taxpayers as to what constituted an acceptable plan. For example, during the early post-World War II period employers and employees deliberately avoided the representation that compensation earned by employees had been deferred at their own request because of fear that this would lead the IRS to find constructive receipt. ${ }^{70}$ As an added precaution, the employee's rights under the unfunded plan often were made subject to the possibility of a forfeiture in order to satisfy the "substantial limitation" requirement of Regulation section $1.451-2^{71}$ in the event that the contractual deferral itself failed to suffice for that purpose. Others feared that an employer's contractual promise to pay might be characterized as a cash equivalent taxable on a current basis. ${ }^{72}$ As a result, some wary taxpayers took the precaution of making the unsecured promise subject to contingencies so that valuation of the deferred payments would be impossible. ${ }^{73}$ On the other hand, there were those who considered the contractual limitation on the right to receipt of payments to be sufficient. These taxpayers relied primarily on a number of cases that supported their position, ${ }^{74}$

68. Commissioner v. Olmsted Inc. Life Agency, 304 F.2d 16 (8th Cir. 1962), affg 35 T.C. 429 (1960), nonacq. 1961-2 C.B. 6; Commissioner v. Oates, 207 F.2d 711 (7th Cir. 1953), affg 18 T.C. 570 (1952), acq., withdrawing prior nonacq., 1960-1 C.B. 5; Basil F. Basila, 36 T.C. 111 (1961); Ernest K. Gann, 31 T.C. 211 (1958), acq. 1960-1 C.B. 4; Howard Veit, 8 T.C. 809 (1947); Pedro Sanchez, 6 T.C. 1141, affd, 162 F.2d 58 (2d Cir. 1947), cert. denied, 332 U.S. 815 (1947); Kay Kimbell, 41 B.T.A. 940 (1940). Such a deferral is subject to the condition that the agreement represent an arm's length business transaction and not a mere subterfuge for the purpose of postponing income tax. See Basil F. Basila, 36 T.C. 111 (1961); Howard Veit, 8 T.C. 809 (1947).

69. See, e.g., Commissioner v. Oates, 207 F.2d 711 (7th Cir. 1953), aff g 18 T.C. 570 (1952), acq., withdrawing prior nonacq., 1960-1 C.B. 5; E.T. Sproull, 16 T.C. 244 (1951), affd, 194 F.2d 541 (6th Cir. 1952); Howard Veit, 8 T.C. 809 (1947).

70. McDonald 206; see 1 WASHINGTON \& RothSCHILD 112; Lasser \& Rothschild, supra note 1 , at 95 .

71. See note 61 supra and accompanying text.

72. See text accompanying note 51 supra.

73. McDonald 208-09.

74. In two related cases, Howard Veit, 8 T.C. 809 (1947), acq. 1947-2 C.B. 4, and Howard Veit, 8 T.C.M. 919 (1949), the court made it evident that a cash basis taxpayer can effectively defer income if he enters into an arms-length agreement to defer before income is due and payable. Similarly, in James F. Oates, 18 T.C. 570 (1952), aff'd, 207 F.2d 711 (7th Cir. 1953), acq., withdrawing a prior nonacq., 1960-1 C.B. 5, the court held that where insurance agents upon retirement may elect to amend their contracts and receive renewal premiums in monthly installments over a period not to exceed 180 months or to abide by an existing contract and receive commissions in cash as they are paid to the company, election to defer shall not put an agent in constructive 
notwithstanding indications that the IRS was not in agreement. ${ }^{75}$ In 1960 , however, the Service allayed all fears when it gave its approval, in Revenue Ruling $60-31,{ }^{76}$ to a very liberal interpretation of the doctrine of constructive receipt while at the same time announcing the inapplicability of the economic benefit rule to unfunded arrangements. The unfunded plan could be elective and nonforfeitable, and there were to be few, if any, restraints on its availability.

Revenue Ruling 60-31 has become the cornerstone of the modern nonqualified deferred compensation plan. ${ }^{77}$ The ruling established the proposition that a contract postponing the right to receive payment for services, which was entered into before amounts were due and payable, would act to take the arrangement outside the scope of the constructive receipt doctrine. ${ }^{78}$ Beyond this, two express provisions of the ruling are especially significant for present purposes: first, "[a] mere promise to pay, not represented by notes or secured in any way, is not regarded as a receipt of income within the intendment of the cash receipts and disbursements method;" tions thereunder] cannot be administered by speculating whether the payor would have been willing to agree to an earlier payment."80 Thus, the ruling established a point already mentioned, namely, that unfunded plans are not within the operation of the economic benefit rule. It further established, however, that the Service would not scrutinize arrangements to determine at whose behest they were created. ${ }^{81}$ While the Service has currently assumed a more restrictive position for ruling purposes, ${ }^{82}$ this substantially remains the law as currently ad-

receipt. Rather, agents are taxable only on the amounts which they actually receive in each of the taxable years, and are not taxable on commissions credited to their accounts which they did not receive and are not entitled to receive under their contract until some future year.

75. For example, the IRS originally published a nonacquiesce in respect to Oates. 1952-2 C.B. 5. It was not until 1960 that the IRS replaced its prior nonacquiescence in the decision with an acquiescence. 1960-1 C.B. 5.

76. 1960-1 C.B. 174, modified by Rev. Rul. 64-279, 1964-2 C.B. 121 (announcing that advance rulings would be issued in respect to nonqualified deferred compensation plans); Rev. Rul. 70-435, 1970-2 C.B. 100 (example 5 of Rev. Rul. 60-31 modified in light of Ray S. Robinson, 44 T.C. 20 (1965), acq. 1970-2 C.B. xxi).

77. See authorities cited in note 62 supra.

78. 1960-1 C.B. 174 (examples $1,2 \& 3$ ).

79. Id. 177.

80. Id. 178.

81. Id.

82. In 1971, the IRS issued Rev. Proc. $71-19$ in which it was stated that for ruling purposes, for any election subsequent to the beginning of the service period, the plan must set forth "substantial forfeiture provisions that must remain in effect throughout the entire period of the deferral." 1971-1 C.B. 698. It has been observed further that the Service (as of January 1977) required that the following conditions be satisfied before it would rule on the tax consequences of an elective deferred compensation arrangement: 
ministered. Accordingly, one commentator has observed of nonqualified plans that "[t]he possibilities are endless, and little or no requirements are imposed by the Code or the Internal Revenue Service, if the total compensation is not unreasonable, if the employee does not have a right to demand earlier payment, and if the amount is not funded."83

\section{Proposed Regulation Section 1.61-16}

\section{A. Background-A Response to Policy Objectives.}

The first major initiative for a departure from the law as stated by Revenue Ruling 60-31 came from Congress. The House version of the 1969 Tax Reform Act $^{84}$ would have continued to tax deferred compensation in accordance with Revenue Ruling 60-31. However, to the extent that the deferred compensation exceeded $\$ 10,000$ a year, the House proposed to tax the income at the rates that would have been applicable had the income been received when earned. ${ }^{85}$ In the words of the House Committee report:

It is anomalous that the tax treatment of deferred compensation should depend on whether the amount to be deferred is placed in a trust or whether it is merely accumulated as a reserve on the books of the employer corporation. An employee who receives additional compensation in the form of a promise to pay him that compensation in the future made by a large, financially sound corporation, is probably as likely to receive the compensation as an employee whose deferred compensation is placed in trust. Your committee believes that the possibility of shifting income to taxable years after retirement when the marginal tax bracket is expected to be lower should not be

(1) The initial election of deferral of payment must irrevocably designate the time and manner of payment.

(2) The employer must not be obligated to hold an annuity contract, life insurance policy or other assets as the funding vehicle to provide the benefits, although it may in its own discretion choose to do so.

(3) Although an employee can elect the form of hypothetical or actual investment which is to be used as a technique to measure any appreciation on the original amount of his deferred payments, the employer must retain the right to veto in its absolute discretion any investment selected by the employee or to make no investment at all.

(4) Benefit payments can commence only upon death, termination of employment, retirement or an emergency.

(5) The payment in the case of an emergency can only take place in instances of hardship arising from causes beyond the employee's control and the payment, if made in such a case, must be limited to the amount necessary to meet such hardship.

Field, Deferred Compensation, 35 N.Y.U. INST. FED. TAX. 1511, 1522 (1977); see Fischer, supra note 62 , at 891 .

83. Jones, supra note 62 , at $979-80$.

84. H.R. Rep. No. 413, 91 st Cong., 1st Sess. 90 (1969), reprinted in [1969] U.S. CODE CoNG. \& AD. NEWS 1738.

85. 1969 S. REP. 307, reprinted in [1969] U.S. CODE CONG. \& AD. NEws 2027, 2346. 
available to employees who are in a position to bargain for deferred compensation arrangements and to rely on the unsecured obligation of their employers, when such benefits are not available to other employees. $^{86}$

The House provision was deleted by the Senate, however, at the request of the Treasury Department, which indicated that the matter required

86. H.R. ReP. No. 413, 91st Cong., 1st Sess. 90 (1969), reprinted in [1969] U.S. Code CoNo. \& AD. News 1738.

As the Senate report explains, the concern addressed by the House was that key employees enjoy the advantage, not shared by other employees, of being able to negotiate with their employers to avoid "the graduation in the present tax structure intended to be generally applicable." 1969 S. REP. 307, reprinted in [1969] U.S. CODE CoNG. \& AD. NEws 2027, 2346. The equalization of income through progressive taxation and social expenditures is an accepted and operative principle of taxation. See Hearings, supra note 2, at 809 (statement of Murray L. Weidenbaum, Director, Center for the Study of American Business, Washington Univ.), reprinted in Daily Tax Rep. (BNA) 2 (Special Supp. Aug. 29, 1978); R. FREEmAN, supra note 2, at 6. However, there remains the question of how progressive a system is desirable. This question is often answered in the policy choices made by Congress that presumably reflect the dominant values of our society. However, American notions of individualism which have served a normative function in the past have been largely displaced in recent decades. Indeed, in many respects an egalitarian ethic has emerged as an operative force in American society that may require the rethinking of basic policies.

Perhaps the most noted statesman of this new ethic is John Rawls. Rawls states that in the just society, "[e]ach person is to have an equal right to the most extensive total system of equal basic liberties compatible with a similar system of liberty for all." J. RAwLs, supra note 16, at 302 . Indeed, "[s]ocial and economic inequalities are to be arranged so that they are . . . to the greatest benefit of the least advantaged." Id. "To the juridical equality of the liberal principle is added a right to an equal share in possession." Scheltens, The Social Contract and the Principle of Law, 17 INT'L PHILosophical Q. 317, 328 (1977).

It should be noted that the business community is itself becoming aware of the shifting American perspective. George Cabot Lodge has urged the business world to meet the challenge of society's current revaluation with imagination. Lodge, Business and the Changing Sociely, 52 HARv. Bus. Rev. 59 (1974). He describes that revaluation in terms not unlike those suggested by Rawls:

Today there is a new right which clearly supersedes property rights in political and social importance. It is the right to survive-to enjoy income, health, and other rights associated with membership in the American community or in some component of that community, including a corporation. ...

The right derives not from any individualistic action or need; it does not emanate from contract. It is a communitarian right the public opinion holds to be consistent with a good community. It is a revolutionary departure from the old Lockean conception under which only the fit survive.

Id. 65. See generally Lodge, supra, for a discussion of the problems growing out of these changes and the varied corporate responses.

Of course, many are unprepared to follow Rawls to his ultimate conclusions. Indeed, there are those who view any such insistence on equality of result as well as equality of opportunity as economically-if not ideologically-disastrous. See generally Kraus, supra note 3. Nonetheless, certain current policies reflect at least a moderate adaptation of the Rawlsian thesis. See Lodge, supra.

Against this background, it is suggested that the executive deferred compensation arrangement is essentially a tax avoidance device fundamentally out of step with social policies and the proper operation of a progressive tax system. In short, the overall reduction of income differentials is a progressive trend which the typical executive compensation package tends to defeat. 
further study and that an alternative solution might be preferable. ${ }^{87}$

In 1972, while it continued to study the issues presented by nonqualified income deferral plans, the Treasury Department proposed regulations dealing with qualified plans. ${ }^{88}$ The Department found the elective nature of many such plans disturbing. The proposal would have amended Code sections 401 (regulating qualified trusts), 403 (regulating qualified annuity plans) and 405 (regulating qualified bondpurchase plans) in order to clarify the tax treatment of contributions to such plans. ${ }^{89}$ Under the proposed regulations, employer contributions to a qualified deferred compensation arrangement were to be regarded as employee contributions whenever such contributions were made at the employee's individual option in return for a reduction in his compensation, or in lieu of an increase. As a result, contributions to an elective qualified plan were to be taxable to the employee on a current basis. ${ }^{90}$

In order to allow time for congressional study of the 1972 proposal, section 2006 of ERISA ${ }^{91}$ provided for a temporary freeze of the status quo. The Revenue Act of 1978 finally disposed of the issue of the proper treatment of elective qualified salary reduction plans by rejecting the proposed changes outright. ${ }^{92}$ Salary reduction plans will

87. 1969 S. REP. 307, reprinted in [1969] U.S. CODE CONG. \& AD. News 2027, 2346. The Finance Committee reported that "[t]he Treasury Department has undertaken a comprehensive study of both qualified and nonqualified employee benefit plans, and it intends, as part of this study, to develop recommendations dealing with the tax consequences of all deferred compensation arrangements." Id.

88. Proposed Treas. Reg. $\S \S 1.402(a)-1(a)(1)(i), 1.403(a)-(1)(a), 1.405-3(a)(1), 37$ Fed. Reg25,938-39 (1972).

89. $I d$.

90. See [1978] I FED. TAX Guide REP. (CCH) If 8473 (New Developments). Although technically the proposed regulations were confined to qualified salary reduction plans, their implications reached all plans under which the employee was given a choice of benefits, some of which are currently taxable. See Metzer (case study of the salary reduction plan examining its contemplated treatment under the proposed regulation).

91. Employment Retirement Income Security Act of 1974, Pub. L. No. 93-406, § 2006, 88 Stat. 822). Under ERISA, the tax treatment of contributions to salary reduction plans in existence on June 27, 1974, was governed by the law as it was applied prior to January 1, 1972. This treatment was to continue at least through December 31,1976 , or until regulations were issued in final form. However, in the case of plans begun after June 27, 1974, contributions to a qualified salary reduction plan were to be treated as employee contributions. The Tax Reform Act of 1976 extended the temporary freeze on the status quo until January 1,1978 , in order to allow additional time for congressional study of the area. Tax Reform Act of 1976, Pub. L. No. 94-455, § 1506, 90 Stat. 1739 (amending ERISA § 2006).

92. The proposed regulations were actually withdrawn in July 1978. However, the withdrawal of the proposed regulations was not intended to represent a change in the Internal Revenue Service's position. S. Rep. ON H.R. 13511, at 77. Section 135 of the Revenue Act of 1978 provides that a participant in a qualified cash or deferred arrangement will not have to include in income any employer contribution to the plan merely because he could have elected to receive such amount in cash instead. Revenue Act of 1978, Pub. L. No. 95-600, § 135, 92 Stat. 2785. 
again be treated as tax-qualified provided they satisfy the law with respect to such plans as it was administered prior to the date of the announced proposals for change. ${ }^{93}$

The evolution of proposed regulation section $1.61-16^{94}$ took a different route. In 1972, the Internal Revenue Service issued the first of a series of favorable private letter rulings approving Revenue Ruling 6031 's treatment of unfunded deferred compensation arrangements between governmental employees and state and local government employers. ${ }^{95}$ This treatment was viewed as particularly problematic because governmental employers are tax-exempt. Where the employer is a taxable entity, his payment of deferred income to the employee is not immediately deductible. The requirement that the employer postpone his deduction until actual distribution of deferred income thus creates a natural constraint on the use of the unfunded arrangement. The tax-exempt employer is under no similar constraint. Perhaps because of this absence of tax-related employer constraints, there were many plans in operation which permitted governmental employees to elect to defer a portion of salary that would otherwise be payable. Disturbed by the elective nature of such plans, the IRS stopped issuing private rulings with respect to them and announced the suspension of rulings pending review of the area. ${ }^{96}$ The problem was perceived to sound in constructive receipt: "The IRS is concerned that, in substance, the employee receives the compensation and deposits it with the employer to be held for the employee's benefit." 97 This concern with elec-

93. The Senate report explains the reasons for the change:

Since the enactment of ERISA the freeze of the status quo treatment of cash or deferred profit-sharing plans has prevented employers from setting up new plans of this type for their employees. Originally, it was thought that a relatively short period of time would be needed for Congressional study and that a permanent solution would be in place by January 1, 1977. The committee believes that the uncertainty caused by the present state of the law has created the need for a permanent solution which permits employers to establish new cash or deferred arrangements. Also, the committee believes that present law discriminates against employers who had not established such arrangements by June 27, 1974.

S. REP. ON H.R. 13511, at 77 .

94. Proposed Treas. Reg. \& 1.61-16, 43 Fed. Reg. 4638 (1978).

95. H. R. REP. ON H.R. 13511 , at 50.

96. Int. Rev. News Rel. 1881 (Sept. 7, 1977), reprinted in 1977-2 U.S. TAX WeEK 1131.

97. Id. The Revenue Act of 1978, Pub. L. No. 95-600, \& 131, 92 Stat. 2779, adds a new section 457 to the Code to provide certainty with respect to unfunded deferred compensation plans maintained by state and local governments. Elective deferral of income is permitted for the lesser of $\$ 7500$ or $33-1 / 3 \%$ of the participant's includible compensation for the taxable year. An eligible state deferred compensation plan cannot make benefits available to participants earlier than their separation from service with the sponsoring entity or the occurrence of an unforeseeable emergency. The new provision stresses that all property or rights to property purchased with the amounts deferred, and any income earned on the property purchased with amounts deferred, must remain assets of the plan sponsor subject to the claims of its general creditors. While plan partici- 
tive government employee plans was reflected on a larger scale with respect to nonqualified plans generally in the full regulation which was proposed in February of 1978-Proposed Regulation section 1.61-16.98

\section{B. Proposed Regulation Section 1.61-16.}

Proposed Regulation section 1.61-16 represents an outgrowth of the developments outlined above. It provides that if a taxpayer (whether or not an employee) individually chooses to defer the receipt of some portion of his current compensation until a later year, the deferred amount will nevertheless be treated as received by the taxpayer in the year when it was earned. The provisions of the regulation would apply to nonqualified plans only. ${ }^{99}$ Significantly, for the purposes of the regulation, it would be immaterial that the taxpayer's rights in the amounts deferred became forfeitable by reason of his exercise of the option to defer payment. ${ }^{100}$

pants may select among optional methods provided under the plan for investing deferred compensation, they cannot have any secured interest in the assets purchased with their deferred compensation.

98. Proposed Treas. Reg. § 1.61-16, 43 Fed. Reg. 4638, 4639 (1978).

99. Although it is not apparent by the terms of the proposed regulation, the contemplated changes were only to extend to unfunded nonqualified arrangements. This is made clear by the language of the Revenue Act of 1978, which rejects the proposed change: "The taxable year of inclusion in gross income of any amount covered by a private deferred compensation plan shall be determined in accordance with the principles set forth in regulations, rulings, and judicial decisions relating to deferred compensation which were in effect on February 1, 1978." Revenue Act of 1978, Pub. L. No. 95-600, § 132(a), 92 Stat. 2782. The Act provides that the term "private deferred compensation plan" does not include "an annuity plan or contract described in section 403" of the Code (a funded arrangement), id. $\S 132(\mathrm{~b})(2)$; "that portion of any plan which consists of a transfer of property described in section 83" of the Code (again pertaining to funded arrangements), id.; nor "that portion of any plan which consists of a trust to which section 402(b) of such Code applies" (pertaining to trust funds), id. This understanding of the deferred compensation plan as limited to unfunded arrangements undoubtedly coincides with the intention of Proposed Treasury Regulation section 1.61-16. An examination of the rulings which are regarded as implicated by the proposed changes corroborates this assertion. See notes 101-04 infra and accompanying text.

100. The text of the proposal is as follows:

(a) In general. Except as otherwise provided in paragraph (b) of this section, if under a plan or arrangement (other than a plan or arrangement described in sections 401(a), 403(a) or (b) or 405(a)) payment of an amount of a taxpayer's basic or regular compensation fixed by contract, statute, or otherwise (or supplements to such compensation, such as bonuses, or increases in such compensation) is, at the taxpayer's individual option, deferred to a taxable year later than that in which such amount would have been payable but for his exercise of such option, the amount shall be treated as received by the taxpayer in such earlier taxable year. For purposes of this paragraph, it is immaterial that the taxpayer's rights in the amount payment of which is so deferred become forfeitable by reason of his exercise of the option to defer payment.

(b) Exception. Paragraph (a) of this section shall not apply to an amount payment of which is deferred as described in paragraph (a) under a plan or arrangement in existence on February 3, 1978 if such amount would have been payable, but for the taxpayer's exercise of the option, at any time prior to (date 30 days following publication of this section as a Treasury decision). For the purposes of this paragraph, a plan or 
Because the proposed regulation represented a complete departure from existing law in the area of nonqualified deferred compensation plans, the effect of the regulation on current plans would have been monumental. Indeed, according to the Treasury, ${ }^{101}$ if the regulation were to be published as a Treasury decision, a whole series of revenue rulings would no longer be applied ${ }^{102}$ and present Service acquiescences in certain key cases ${ }^{103}$ would have to be reconsidered. ${ }^{104} \mathrm{De}-$ spite the Service's apparent longstanding acquiescence in the present state of the law, however, the concerns which surfaced in this regulation are not of recent origin. The Service has never been entirely comfortable with the liberal treatment afforded nonqualified plans by Revenue Ruling 60-31, as is evidenced by its ever-changing stance on rulings during the 1960 s. ${ }^{105}$

The proposed regulation addressed one central problem created by current law-that key employees enjoy the advantage, not shared by other employees, of being able to negotiate with their employers to avoid "the graduation in the present tax structure intended to be generally applicable." 106 In the view of both the IRS and the Treasury Department, the problem has become particularly acute since the passage of ERISA, which resulted in an increased use of nonqualified plans. ${ }^{107}$

arrangement in existence on February 3,1978 which is significantly amended after such date will be treated as a new plan as of the date of such amendment. Examples of significant amendments would be extension of coverage to an additional class of taxpayers or an increase in the maximum percentage of compensation subject to the taxpayer's option.

Proposed Treas. Reg. § 1.61-16, 43 Fed. Reg. 4638, 4639 (1978).

101. Treas. Dep't. Explanation of Proposed Regulation \$ 1.61-16, 43 Fed. Reg. 4638 (1978).

102. The rulings cited by the Treasury Department were: Rev. Rul. 71-419, 1971-2 C.B. 220 (directors' fees deferred despite the fact that the corporation maintained a separate memorandum account of amounts deferred by each director, and notwithstanding the fact that the corporation credited the account with interest at a specified rate); Rev. Rul. 69-650, 1969-2 C.B. 106 (income is not constructively received where an irrevocable election is made to defer a portion of salary and where the amounts deferred were satisfied from general corporate funds subject to creditors' claims); Rev. Rul. 68-86, 1968-1 C.B. 184 (deferral permitted if employee elected bonus in employer stock subject to restrictions significantly affecting its value); Rev. Rul. 67-449, 1967-2 C.B. 173 (tax deferral achieved through "substantial forfeiture" provisions). 43 Fed. Reg. 4638 (1978).

103. The cases which would have required reconsideration were: Ray S. Robinson, 44 T.C. 20 (1965), acq. 1970-2 C.B. xxi (prizefighter held taxable in 1957 only for those proceeds from fight actually received in 1957 under contract with promoter providing for payment of balance over three-year period); James F. Oates, 18 T.C. 570 (1952), affd, 207 F.2d 711 (7th Cir. 1953), acq., withdrawing prior nonacg. 43 Fed. Reg. 4638 (1978). See note 74 supra.

104. The Treasury Department stated that it would also be necessary to examine the facts and circumstances of a number of other rulings and cases reflecting similar patterns to determine at whose election deferral of payment of compensation was arranged, e.g., Rev. Rul. 72-35, 1972-1 C.B. 127; Rev. Rul. 68-99, 1968-1 C.B. 193; Rev. Rul. 60-31, 1960-1 C.B. 174 (examples 1 and 3).

105. For an exhaustive list of Service maneuverings, see Metzer 538-39 n.52.

106. 1969 S. REP. 307, reprinted in [1969] U.S. CODE CoNG. \& AD. NEws 2027, 2346.

107. See text accompanying notes $20-28$. 
The proposed regulation was regarded as an answer to that growing concern. Unfortunately, there were problems inherent in the proposal-both theoretical and practical-that may have contributed to Congress' decision to reject it. ${ }^{108}$

\section{The Problems with the Proposed Change.}

The proposed regulation presented several practical difficulties. Most notably, the promulgation of the regulation would have given rise to a great many problems in administration. As the IRS observed, "the statute [section 451 and regulations thereunder] cannot be administered by speculating whether the payor would have been willing to agree to an earlier payment." 109 The case-by-case determination of whether deferral was at the taxpayer's option or was mandated by the employer would have created an obvious problem of proof with which neither the Service nor the courts may have been able to contend. ${ }^{110}$ Furthermore, problems of proof undoubtedly would have been complicated by the automatic tactical adjustments that the business community would have made. Differences in interpretation as to what constitutes an employer-mandated plan as opposed to an elective plan would have compounded problems of abuse and further obscured application of the regulation.

Finally, the proposed regulation presented a practical problem of a different kind that perhaps was most responsible for its defeat-the changes that it would have introduced simply were viewed as too drastic. ${ }^{11}$ The regulation effectively would have eliminated the vast majority of executive deferred compensation arrangements currently in use. Wherever deferral was made at the employee's option, no forfeiture provision-however severe-would have operated in any way to inhibit application of the regulation. Without passing on the merits of such a result, it suffices to say that it probably exceeded any change that the business community and the current Congress were willing to toler-

108. See text accompanying note 7 .

109. Rev. Rul. 60-31, 1960-1 C.B. 174, 178.

110. None of the rulings or cases cited by the Treasury Department for reconsideration involved a determination that the deferral arrangement was elective. The elective or nonelective nature of the plan was not in issue in any of these cases nor was it thought to be at all relevant. See notes 101-04 supra and accompanying text.

111. In rejecting the proposed regulation, the House Ways and Means Committee stated:

The committee believes that the doctrine of constructive receipt should not be applied to employees as would be provided in the proposed regulations concerning nonqualified deferred compensation plans issued by the Internal Revenue Service on February 3,1978 . The committee also believes that the uncertainty surrounding the status of private nonqualified deferred compensation plans caused by the proposed regulations is not desirable and should not be permitted to continue.

H.R. REP. ON H.R. 13511, at 60. 
ate.

\section{The Theoretical Basis of the Proposed Regulation.}

Because Proposed Regulation section 1.61-16 has been rendered moot by the Revenue Act of $1978^{112}$ an examination of its theoretical underpinnings may, at first glance, appear to be merely academic. However, the inquiry goes to a larger concern: the relationship between theory and result. Essentially, only two theories operate with respect to nonqualified plans-the doctrine of constructive receipt and the economic benefit rule. Some have argued that a third theory-the doctrine of assignment of income-also is applicable. In any event, as a conceptual matter, the regulation of nonqualified deferred compensation arrangements necessarily rests upon one of these doctrinal bases. The task, therefore, is to distinguish both the theories and the results that can be effected by resort to each of them.

The Treasury Department and the IRS arrived at divergent viewpoints regarding the legal basis upon which to justify Proposed Regulation section 1.61-16. Each position will be examined in turn, with particular emphasis on the view adopted by the IRS.

The Treasury Department position turns on an application of notions of constructive receipt. ${ }^{113}$ Although it would represent a departure from prior decisional law, it is arguably correct to apply the constructive receipt doctrine to self-imposed limitations on the right to receive income. To say that a taxpayer who engineers the deferral of some part of his income by contractual arrangement lacks substantial control of its receipt is to ignore practical realities in favor of form. Thus, the Treasury Department's decision to treat amounts so deferred as currently taxable income may represent a simple refusal to continue to favor form over substance.

While a contract providing for deferred compensation may impose a legitimate restraint on a taxpayer's right to receive income, where the agreement is made at the taxpayer's request, he may fairly be deemed to have turned his back on income otherwise available. Logically, this is so even if the amounts deferred are made subject to the possibility of a forfeiture, since forfeiture provisions may be avoided entirely if a taxpayer elects to receive all income on a current basis. It is an accepted principle that a taxpayer who has received income-whether actually or constructively-incurs a current tax liability, irrespective of any sub-

112. See note 7 supra.

113. This is the position that was assumed by the Treasury Department, according to one department official informally interviewed (Sept. 12, 1978). 
sequent disposition of the income. ${ }^{114}$ Thus, the proposed regulation correctly disregarded the presence of forfeiture provisions by treating them as irrelevant to the question of constructive receipt as that doctrine was interpreted for purposes of the regulation. ${ }^{115}$ As a practical matter, however, the failure of the regulation to distinguish between forfeitable and nonforfeitable plans probably added to the perceived severity of the proposed change.

The theory adopted by the IRS with respect to the proposed regulation is not as easily justified as that of the Treasury Department. The Service grounds the recent proposal in the doctrine of assignment of income. ${ }^{116}$ Apparently, the IRS reasons that a voluntary deferral of income through an unfunded arrangement is an assignment of income to the employer-promisor and thus taxable to the person who earns it on a current basis. 117

The underlying principle of the assignment of income doctrine is that income shall be taxable to the person who earns it and that the tax cannot be avoided by anticipatory assignments of the income to others. ${ }^{118}$ It is clear, therefore, that the IRS' application of the assign-

114. Treas. Reg. \& 1.451-I(a) (1971).

115. See note 100 supra.

116. This is the position that was adopted by the IRS as was indicated by one agency official during the course of an informal interview (Sept. 12, 1978).

117. In principle there is no reason why the same analysis would not be equally applicable to funded arrangements. A voluntary deferral of income in that context might be regarded as an assignment of income to the trust, escrow agent or insurance company that is providing the funding mechanism. However, the reach of the proposed changes was limited to unfunded arrangements. See note 99 supra.

118. The first formal enunciation of the doctrine of assignment of income was in 1930 when the Supreme Court in Lucas v. Earl, 281 U.S. 111 (1930), held a taxpayer liable for income tax upon the whole of his salary and attorney's fees even though he had made a valid prior assignment of one-half to his wife. In the words of Justice Holmes, speaking for the Court, "There is no doubt that the statute could tax salaries to those who earned them and provide that the tax could not be escaped by anticipatory arrangements and contracts however skillfully devised to prevent the salary when paid from vesting even for a second in the man who earned it." Id. at 114-15. In a series of cases that followed Lucas, the same principle was applied. E.g., Harrison v. Schaffner, 312 U.S. 579 (1941); Helvering v. Eubank, 311 U.S. 122 (1940); Helvering v. Horst, 311 U.S. 112 (1940); Burnet v. Leininger, 285 U.S. 136 (1932); Armantrout v. Commissioner, 570 F.2d 210 (7th Cir. 1978) (per curiam), affg 67 T.C. 996 (1977); Wilson v. United States, 530 F.2d 772 (8th Cir. 1976); Duran v. Commissioner, 123 F.2d 324 (10th Cir. 1941); Commissioner v. Bonwit, 87 F.2d 764 (2d Cir.), cert. denied, 302 U.S. 694 (1937); Ronan State Bank v. Commissioner, 62 T.C. 27 (1974). See also Commissioner v. Culbertson, 337 U.S. 733 (1949); Lusthaus v. Commissioner, 327 U.S. 293 (1946); Commissioner v. Tower, 327 U.S. 280 (1946).

An analysis of the doctrine of assignment of income reveals that it is in fact little more than an aspect of the economic benefit rule requiring a taxpayer to pay taxes on all income received in cash or its equivalent. When one earns the right to receipt of income and directs it to be paid to a third party in satisfaction of a debt or as a gift, one has received the equivalent of direct payment and is taxable on that basis. As explained in Helvering v. Horst, 311 U.S. 112, 116-17 (1940):

[U]nderlying the reasoning in these cases is the thought that income is "realized" by 
ment of income doctrine to deferred compensation arrangements reflects an elementary misunderstanding of the concept. While assignment of income involves a voluntary disposition of income in favor of a third party, ${ }^{119}$ the question posed in the present context is the proper tax treatment of income deferral. ${ }^{120}$ There is no doubt that the employee will be taxable on the deferred income; rather, the question concerns the proper timing of the taxation.

Although the concept of assignment of income is relatively straightforward, a number of fairly recent cases have done much to obscure it. ${ }^{121}$ One easily misunderstood case, United States v. Bayse, ${ }^{122}$

the assignor because he, who owns or controls the source of income, also controls the disposition of that which he could have received himself and diverts the payment from himself to others as the means of procuring the satisfaction of his wants.

119. See Helvering v. Eubank, 311 U.S. 122 (1940); Helvering v. Horst, 311 U.S. 112 (1940); Duran v. Commissioner, 123 F.2d 324 (10th Cir. 1941).

120. The distinction between a disposition or assignment of income and a mere deferral is drawn in clear terms in James F. Oates, 18 T.C. 570 (1952). Referring to Lucas, Eubank and Horst, the court stated:

Those are cases where the income had been assigned to another and the taxpayer was contending that the assignment relieved him of taxation on the income and that the income was taxable to the one to whom it had been assigned. We have no such question here. Petitioners are making no contention that the commissions credited to their account . . . in the taxable years will not be taxable to them if and when they receive them. Their contention is that under their amended contracts ... they were not entitled to receive any more than they did in fact receive and that being on the cash basis they can only be taxed on these amounts and that the remainder will be taxed to them if and when received by them.

Id. at 585 .

This passage was later quoted by the court in Ernest K. Gann, 31 T.C. 211, 219 (1958), acq. 1960-1 C.B. 4 , in order to make the identical point when again the argument of assignment of income was raised in the context of a deferral.

121. In Llewellyn v. Commissioner, 295 F.2d 649 (7th Cir. 1961), a pathologist modified his employment contract with two hospitals in order to have a portion of his compensation applied to the purchase of annuities for him. His assumption was that the arrangement would qualify under section 403 of the Code because the hospital-employer was tax-exempt (under the provisions of I.R.C. $\$ 501$ ). However, the court determined this issue against him, declining to characterize the payments made to the insurance company as "employer contributions" within the meaning of section 403(a) of the Code, and further noting that "the amounts deducted from Dr. Llewellyn's percentage of the gross receipts and paid out, at his direction, to Phoenix Mutual [from whom the annuities were purchased], were not employers' contributions, but were income constructively received by Dr. Llewellyn and as such constitutes taxable income to him." Id. at 651. However, although the amounts applied to the purchase of annuities were properly taxable on a current basis as a matter of the doctrine of cash equivalence or economic benefit, or upon the basis of the somewhat overlapping concept of constructive receipt, the court regrettably placed the holding of the case on a different footing, stating that "[i]n effect, Dr. Llewellyn [had] made anticipatory assignments of part of his income to Phoenix Mutual." Id. The difficulty with the court's position is that the case did not turn upon a consideration of to whom the income should be taxable. See note 95 supra and accompanying text.

In Hicks v. United States, 314 F.2d 180 (4th Cir. 1963), the Fourth Circuit opted for a similar analysis. There the taxpayer had the right to take an annual bonus either entirely in cash, or partly in cash and partly in the form of an interest in a qualified trust. Since the trust was subject only to a five percent penalty for early withdrawal it was essentially nonforfeitable. Determining 
has particularly attracted the attention of the IRS. In fact, the case is central to its understanding of the proposed change. ${ }^{123}$ Bayse will be examined here for two purposes: to arrive at an understanding of both the principle of the case and the Service's application of it; and to further distinguish both the theories operative in the area of deferred compensation and the results that can be effected by them.

Bayse involved a complicated fact situation. Assignment of income clearly was the basis for the decision, but it is unclear at what level of the decision it came into play. The case involved a medical partnership that performed services for a prepaid health plan. At the request of the partnership, the health plan was required by the terms of the service contract to make annual payments into a retirement trust for the benefit of the partners and nonpartner employees of the partnership. No interest in the account was deemed to vest in a particular beneficiary prior to his retirement, and a physician's preretirement severance from the partnership would occasion the forfeiture of his interest. Amounts thus forfeited were redistributed to the remaining participants. ${ }^{124}$ Under no circumstances, however, could the health plan recoup payments once made, and payments made to the trust were not forfeitable by the partnership as such. ${ }^{125}$ The Court held that the retirement fund payments were compensation for services rendered

that an election to participate was, in effect, an "employee contribution," the court, as had the Seventh Circuit in Llewellyn, held the taxpayer taxable on a current basis for amounts paid over to the plan. Again, the court revealed an elementary confusion as to the properly applicable theory, reviewing, in the course of its opinion, cases involving each of the three common law doctrines of constructive receipt, assignment of income and economic benefit. Ultimately, however, the opinion rested on a finding of constructive receipt:

Hicks' written instruction diverting the payment from himself to the trustee was a voluntary act in exercise of his power to dispose of the income represented by that payment. . . Therefore, the payment here involved became available without condition or limitation in 1958, Hicks constructively received it at that time and it was properly subject to the payment of income tax for that year.

Id. at 185.

In the same year in which the Hicks case was decided, the IRS published Rev. Rul. 63-180, 1963-2 C.B. 189, announcing that Hicks would be confined to its facts. The general rule remained that where an employer makes a contribution in behalf of an employee to a qualified trust, the contribution will be tax-deferred until such time as it is distributed or made available to the employee. For an analysis of the Hicks case and the aftermath, see Rothschild \& Ness, IRS Confines Hicks Case and Sanctions Deferred Compensation Choices, 19 J. TAX. 216 (1963).

122. 410 U.S. 441 (1973).

123. The importance of the Bayse decision to the IRS' conception of assignment of income in the context of voluntary deferrals was related to this author during the course of an informal interview with an IRS official (Sept. 12, 1978).

124. Indeed, under the terms of the agreement, the plan was to continue irrespective either of changes in the partnership's personnel or of alterations in its organizational structure. The plan would survive any reorganization of the partnership so long as at least $50 \%$ of the plan's participants remained associated with the reorganized entity. 410 U.S. at 445.

125. Id. 
under the medical-service agreement and should have been reported as income to the partnership. Furthermore, the individual partners should have included their shares of that income in their individual returns, since income fully earned by the partnership is taxable to the partners, regardless of any conditions placed upon their actual receipt of individual shares of that income. ${ }^{126}$

The Supreme Court in Bayse prefaced its opinion by noting that its decision rested on "two familiar principles of income taxation."127 One principle relied upon by the Court was that "partners are taxable on their distributive or proportionate shares of current partnership income irrespective of whether that income is actually distributed to them." 128 The other was "that income is taxed to the party who earns it and that liability may not be avoided through anticipatory assignments of that income." 129 Prior to Bayse, it was clear that a voluntary deferral of income did not fall within the doctrine of assignment of income. ${ }^{130}$ The question is whether Bayse operated to expand the scope of that doctrine so as to include voluntary income deferral arrangements. If one focuses on the individual members of the partnership as the taxable entities in question, it might appear so, for indeed, their interests in the voluntarily deferred payments were forfeitable and yet they were taxed on the income on a current basis. It is clear that the IRS now views the doctrine as so expanded. ${ }^{131}$ However, if such an

126. Id. at 457 .

127. Id. at 447

128. Id.

129. Id.

130. See notes 118-20 supra and accompanying text. A number of commentators have argued that the economic benefit rule is more clearly applicable to the Bayse situation and have questioned the validity of the Court's application of the assignment of income doctrine. See Shapiro, The Bayse Decision One Year Later: Judging Its Effect upon Related Areas, 39 J. TAx. 376, 376-77 (1973); Teschner, Bayse Projected: Fringe Benefits and the Supreme Court, 51 TAxEs 324, 336 (1973); Note, Taxing Retirement Trust Contributions When Made: United States v. Bayse, 27 STAN. L. REv. 1249, 1261 (1975). As an application of the economic benefit rule, Bayse is a relatively easy case. While the partners themselves had no vested interest in the retirement fund, the partnership did. As was already examined above, one who has a nonforfeitable right to amounts paid into a trust fund must include the contributions made in his behalf as current income. See notes 42-45 supra and accompanying text. Hence, the partnership entity was taxable on the amounts paid into the retirement trust on a current basis, and, under applicable partnership law, amounts fully earned and payable to the partnership are taxable to the partners whether or not actually distributed to them. Accordingly, the partners were held accountable for their shares of the deflected partnership income for the year in which it was paid over to the trust. Despite the seeming simplicity of this approach, however, this was not the basis of the Court's analysis. Rather, the Court resorted to a technical application of the doctrine of assignment of income which, though probably correct, was unnecessary to a proper disposition of the case.

131. A number of commentators predicted a development along these lines. For the most part, they agreed that any attempt to rely on Bayse for an alteration of the principles operative in respect to deferred compensation arrangements would be unjustified. See Shapiro, supra note 
interpretation of Bayse is correct, it would appear that Congress' recent rejection of Proposed Regulation section 1.61-16 is in direct conflict with the Supreme Court's decision. It is safe to say, however, that the issue need not be decided in this way. In fact, the opinion indicates that the Court intended that its decision be nothing more than an application of the "familiar principle" of assignment of income. ${ }^{132}$

The Bayse Court was able to rely on the assignment of income doctrine because the case involved the diversion of partnership income to a second person or entity, namely, the ultimate beneficiaries of the trust. The partnership was not the beneficiary of the trust at all; rather, the individual partners were. Moreover, those who ultimately would have taken under the retirement trust arrangement were not necessarily the same persons who earned the income deflected to the fund. ${ }^{133}$ In short, the peculiarities of the arrangement, coupled with the legal status of the partnership entity, worked an anticipatory assignment of income taxable to those who earned it on a current basis. Expansive readings of the case that equate voluntary deferral with assignment of income are simply wrong.

It has been established that the assignment of income doctrine does not aid in the implementation of policy objectives in the taxation of deferred compensation. While Proposed Regulation section 1.61-16 is nonetheless theoretically sound as an application of the doctrine of constructive receipt, it has been abandoned as a solution. However, a consideration of the economic benefit rule suggests yet another basis upon which to implement, at least partially, several policy objectives in the area of nonqualified deferred compensation arrangements. In the next section a moderate proposal for change will be made which utilizes the economic benefit rule. While the proposal would accomplish less than Proposed Regulation section 1.61-16, it may carry with it the benefit of making the proposal more politically feasible.

\section{A Proposal for Change}

\section{A. The Proposal.}

Proposed Regulation section 1.61-16 would have foreclosed the availability of the deferred compensation arrangement to most execu-

130, at 377-79; Teschner, supra note 130, at 353. However, at least one writer appeared to share in the confusion. See Comment, Tax: The Import of Employee Involvement in Determining Own Method of Compensation Reviewed, 58 MINN. L. REv. 1171, 1177, 1179-80, 1187 (1974).

132. As the Court noted in Bayse: "The entity earning the income-whether a partnership or an individual taxpayer-cannot avoid taxation by entering into a contractual arrangement whereby that income is diverted to some other person or entity." 410 U.S. at 449.

133. Id. at 445 . 
tives. ${ }^{134}$ Inasmuch as it appears that the executive deferred compensation arrangement rests on far too strong a footing to be eliminated outright, this Comment proposes that its use simply be curtailed.

Under current tax law, amounts contributed to a funded nonforfeitable arrangement are taxable to the employee on a current basis nonwithstanding a binding contract to defer payment. ${ }^{135}$ In the case of the unfunded plan, however, where such amounts are represented by an unsecured liability of a solvent employer, taxes can be successfully postponed even though the deferred income is nonforfeitable. This distinction is grounded in the language of Revenue Ruling 60-31: "A mere promise to pay, not represented by notes or secured in any way, is not regarded as a receipt of income within the intendment of the cash receipts and disbursement method." 136 The proposal made here challenges the logic of the present statutory distinction between funded and unfunded nonqualified plans. It provides that when an amount credited to an employee on the books of a solvent employer is nonforfeitable when credited to his account, or becomes nonforfeitable thereafter, then, at the time his rights so vest, the employee is the recipient of a present economic benefit taxable to him on a current basis. Income would be conclusively measured by the amount of the deferred obligation, and the passage of time before actual receipt of the deferred income would not be taken into account. This treatment of unfunded plans would parallel current law with respect to funded arrangements.

In the usual case in which the unfunded plan is currently utilized, there is no appreciable difference between a promise to pay in the hands of a solvent employer and a similar promise to pay in the hands of a third-party trustee, escrow agent, or insurance company. ${ }^{137}$ It is clear that, as a practical matter, an employee incurs no great risk when he receives an unsecured promise to pay from a large solvent corporation. Thus, employees of large corporations are able both to defer taxation and to ensure future income by participating in nonforfeitable unfunded deferred compensation plans that carry little or no risk of loss. On the other hand, an employee of a smaller enterprise usually feels the need for greater security in the arrangement to ensure his future retirement income so that such an employee must opt for a funded plan. Thus, he foregoes the opportunity to defer taxation absent conditions of forfeiture restricting the ultimate availability of deferred in-

134. See notes 98-104 supra and accompanying text.

135. I.R.C. $\$ \S 402(b), 403(c)$.

136. 1960-1 C.B. $174,177$.

137. See McDonald 208. 
come. ${ }^{138}$ As a result, the unfunded nonqualified deferred compensation plan has become the almost exclusive province of the highly compensated executive who works for a firm of a size or profitability and stability adequate to assure the "security" of his unsecured compensation deferral. The proposed change would place all nonforfeitable plans on an equal footing, thus eliminating the present law's preferential treatment of high level employees of large corporations.

To whatever extent there may be some practical differences between funded and unfunded plans, policy considerations suggest that these differences do not justify a difference in tax consequences. Nonetheless, current tax law persists in recognizing such a distinction, thus giving greater weight to the peripheral and, for the most part, purely hypothetical risk associated with unsecured arrangements than to practical realities and considerations of overall tax fairness. The proposed regulation would condition the availability of deferred taxation on the forfeitability of the nonqualified plan, whether funded or unfunded. Thus, the proposal would operate to replace the current presumption in favor of executives that the deferred obligation carries no presently taxable value ${ }^{139}$ with a contrary presumption that the present value of the arrangement is the full amount of the deferred obligation. ${ }^{140}$

If the views propounded in this Comment were to take the form of a treasury regulation, it might read as follows:

If under a plan or arrangement (other than a plan or arrangement described in sections 401(a), 403(a) or (b) or 405(a)) payment of an amount of a taxpayer's basic or regular compensation fixed by contract, statute, or otherwise (or supplements to such compensation such as bonuses or increases) is deferred to a taxable year later than that in which it would otherwise be payable, and such plan or ar-

138. Where a fund is deemed necessary to support the employer's promise to pay, deferral is available only at the price of conditions of forfeiture. I.R.C. $\$ \S 402$ (b), 403(c).

139. See text accompanying notes $58,79 \& 83$ supra.

140. There is a noteworthy parallel to this presumption in the language of section 131 of the Revenue Act of 1978. Section 131 of the Act concerns state and local government deferred compensation plans. See note 97 supra. If a government plan does not satisfy the eligibility requirements of the bill, then in the case of an unfunded salary-reduction deferral agreement executed by an employee and a state or local government, the amount withheld by the state or local government will be presumed to be the present value of the compensation deferred. If future payments are subject to a substantial risk of forfeiture then they will not be valued until there is no longer a substantial risk of forfeiture.

Apparently, Congress declined to extend the provisions of section 131 to unfunded nonqualified plans utilized by taxable entities because the considerations differ in the two contexts. See notes 95-96 supra and accompanying text. In the private sector, for example, unfunded nonqualified deferred compensation arrangements are in many instances limited in their coverage to highly compensated managerial employees, see notes 28-31 supra and accompanying text, whereas state and local government plans have heretofore been available on a broad basis to governmental employees at all levels. See S. REP. ON H.R. 13511, at 71. 
rangement takes the form of an unsecured promise to pay, then, in any such instance, and provided that the obligor is solvent at the time the deferral is arranged, the amount of payment so deferred shall be included in the gross income of the taxpayer in the first taxable year in which his rights in the promised payments are not subject to a substantial risk of forfeiture as that term is defined under section 83(c).

In short, the unfunded deferred compensation arrangement-the executive plan par excellence ${ }^{141}$ - would continue to be available, but would be subject in every instance to the overriding requirement of forfeitability. Thus, it would be placed on the same footing as its funded counterpart that is currently regulated under the terms and conditions of sections 402(b) and 403(c) of the Code. The purpose of the regulation would be twofold: first, to limit the general availability of the nonqualified plan, and second, to regulate the unfunded plan further so as to undermine its desirability to some extent. As currently regulated, the unfunded arrangement is particularly attractive because the sole prerequisite to tax deferral treatment is the agreement to defer itself. ${ }^{142}$ Yet, in the words of one commentator, one is "at a loss to understand why the Commissioner should patiently await the receipt of the gain if the taxpayer patiently postpones its receipt. It is . . sufficient that the taxpayer has acquired an unconditional right to be paid and that the right represents an economic gain." 143 The imposition of a uniform forfeitability requirement at least would operate to limit the availability of the unfunded arrangement in a manner capable of objective scrutiny. ${ }^{144}$

\section{B. Legal Justification for the Proposed Treatment of Unfunded Nonqualified Deferred Compensation Arrangements.}

The economic benefit rule concerns what property or rights actually received are to be currently taxable as "income."145 It will be argued in this subsection that, in the context of deferred compensation arrangements, an unfunded and unsecured promise to pay money in the future made by a solvent employer confers a present economic ben-

141. See note 31 supra and accompanying text.

142. See notes $47,59-68$ supra and accompanying text.

143. Eisenstein, supra note 2, at 407.

144. The failure of Proposed Treas. Reg. $§ 1.61-16$ to provide an objective standard for evaluating the taxability of a given deferred compensation arrangement was among its most significant drawbacks.

145. The first formal enunciation of the economic benefit rule was in 1945, when the Supreme Court, in Commissioner v. Smith, 324 U.S. 177 (1945), described the income tax laws as "broad enough to include in taxable income any economic or financial benefit conferred on [any] employee as compensation, whatever the form or mode by which it is effected." Id. at 181 . 
efit upon the employee that should be taxable on a current basis.

As was noted earlier, funded deferred compensation plans are regulated in part by section 83 of the Code, which treats as a currently taxable economic benefit all "property" received by an employee in the form of employer payments into such plans. ${ }^{146}$ Adoption of the proposal set forth in this Comment would require that unfunded promises to pay also be regarded as "property" within the meaning of section 83 . However, the recently promulgated regulations under section 83 are quite specifically to the contrary: “[T]he term 'property' includes real and personal property other than money or an unfunded and unsecured promise to pay money in the future." 147 Thus, unfunded deferred compensation arrangements remain outside the intended reach of section 83. However, a change in the section 83 regulations would be justified if the proposal advanced in this Comment is sound. An examination of the economic benefit doctrine in light of general principles of taxation and the purposes that they are intended to serve will demonstrate the fundamental soundness of the proposed change.

1. The Evolution of the Economic Benefit Doctrine. (a) The cash equivalence rule. As a general rule, a mere promise to pay a specified sum of money in the future has not been considered the equivalent of cash in hand. Rather, such unsecured promises have been characterized as creating no more than an account receivable in the hands of the creditor-a nontaxable item to a cash basis taxpayer. ${ }^{148}$ The traditional rationale for the cash equivalence doctrine is that unless a promise is secured by property or evidence of property that is transferable and has a cash value, the income represented by the promise to pay should not be taxed until received because until such time there is

146. See notes 53-57 supra and accompanying text.

147. Treas. Reg. $\S 1.83-3$ (e) (1978) (emphasis added). This provision was a part of the original regulations proposed in June, 1971. Proposed Treas. Reg. $\$ 1.83,36$ Fed. Reg. 10,787 (1971). Presumably, it was included in order to reflect existing applications of the economic benefit rule and to allay fears that might otherwise have been aroused as to the intended scope of the new section. Indeed, the original impetus behind the enactment of section 83 was to effect some solution to the problems surrounding the taxation of stock options. For the text of section 83 as accompanied by the Senate Committee Report, S. REP. No. 552, 91st Cong., Ist Sess. 119 (1969), and Conference Committee Report, H.R. REP. No. 782, 91st Cong., 1st Sess. 303 (1969), see J. RabKIn \& M. Johnson, supra note 44, at 1270-78. See Helpern, The Unexpected Impact of New Section 83-The Restricted Property Provisions, 24 TAX LAw. 365 (1970-71).

148. See Estate of W.F. Williamson, 29 T.C. 51 (1957), acq. 1958-2 C.B. 8; Harold W. Johnston, 14 T.C. 560 (1950); Alice G.K. Kleberg, 43 B.T.A. 277 (1941); William A. Hines, 38 B.T.A. 1061 (1938); Dudley T. Humphrey, 32 B.T.A. 280 (1935); Charles C. Ruprecht, I6 B.T.A. 919 (1929), affd, 39 F.2d 458 (5th Cir. 1930); John B. Atkins, 9 B.T.A. 140 (1927), affd, 36 F.2d 611 (D.C. Cir. 1929). See also Guffey v. United States, 222 F. Supp. 461 (D. Ore. 1963), affd 339 F.2d 759 (9th Cir. 1964); James B. Ely, 19 T.C.M. (CCH) 743 (1960). 
neither cash nor property available with which to pay the tax. ${ }^{149} \mathrm{Nev}-$ ertheless, although market value and transferability originally were central concepts of the cash equivalence doctrine, traditional notions of cash equivalence are eroding.

For example, it was at one time presumed that it would be wholly inconsistent with the cash basis of reporting to value an unsecured deferred-payment sales contract and to treat that value as money realized in the year in which the sale was consummated. Only negotiable instruments were deemed to be the equivalent of cash. ${ }^{150}$ However, courts in a more recent line of cases have adopted the position that the distinction between the so-called "note and mortgage" cases (involving secured agreements) and the so-called "contract cases" (involving unsecured arrangements) "appears to be illusory."151 In Heller Trust $v$. Commissioner, ${ }^{152}$ for example, unsecured deferred payment contracts executed in connection with the sale of duplexes were valued at fifty percent of the face value of the buyer's obligation and included in the vendor's income in the year of sale, notwithstanding a complete absence of collateral. The court stated:

Petitioners contend that these contracts could not have had an ascertainable fair market value in the particular year received because they did not receive any negotiable instruments as evidence of any indebtedness, i.e., notes and mortgages. This court has heretofore made the observation that such a distinction in some cases appears to be illusory. ${ }^{153}$

In one case noted with particular frequency, Frank Cowden, Sr. ${ }^{154}$ a solvent obligor's unsecured obligation to make deferred payments was held to be worth face value. The court held that if a solvent obligor's unsecured promise to pay is unconditional and assignable, not subject to set-offs, and of a kind that is frequently transferred to lenders or investors at a discount not substantially greater than the generally prevailing premium for the use of money, the face value of such a promise is taxable as the equivalent of cash received by the taxpayer. ${ }^{155}$

149. This reasoning is especially prominent in cases involving sales contracts. See Commissioner v. Garber, 50 F.2d 588 (9th Cir. 1931); Commissioner v. Moore, 48 F.2d 526 (10th Cir. 1931); C.W. Titus, Inc., 33 B.T.A. 928 (1936). See generally 2 J. Mertens, Law of Federal InCOME TAXATION \& 11.05 (1974 ed. \& 1978 Cum. Supp.).

150. Bedell v. Commissioner, 30 F.2d 622 (2d Cir. 1929); Harold W. Johnston, 14 T.C. 560 (1958); Nina J. Ennis, 17 T.C. 465 (1951).

151. Heller Trust v. Commissioner, 382 F.2d 675 (9th Cir. 1967); Phillips v. Frank, 295 F.2d 629 (9th Cir. 1961); Howard A. Perelman, 41 T.C. 234 (1963).

152. 382 F.2d 675 (9th Cir. 1967).

153. Id. at 681 .

154. 32 T.C. 853 (1959), rev'd and remanded, 289 F.2d 20 (5th Cir.), on remand, 20 T.C.M. (CCH) 1134 (1961).

155. This was the ultimate holding of the case on remand to the tax court. Cowden v. Com- 
Although the case turns on traditional notions of marketability, the language of the opinion is nonetheless informative on a larger issue: "The income tax law deals in economic realities, not legal abstractions, and the reach of the income tax law is not to be delimited by technical refinements or mere formalism." 156 Indeed, the economic realities that have led to the expansion of the cash equivalence doctrine also have required courts to abandon traditional nomenclature and to speak instead of the concept of economic benefit.

(b) An expanding concept of economic benefit. The broadening of the doctrine of cash equivalence coincides with an expanding concept of income generally. ${ }^{157}$ Section 61 (a) provides that gross income encompasses "all income from whatever source derived." 158 It is by now axiomatic that a liberal construction is to be given this broad definition of gross income, so that the form which income assumes may often be entirely dissimilar to cash. ${ }^{159}$ Mertens discusses the trend away from more limited notions of cash equivalence and toward generalized notions of economic benefit:

The term [cash equivalence], however, has taken on over the years a broader meaning. Occasionally it means receipt of benefits and at other times it may mean a substitute for income or a flow of satisfaction or a benefit accrued. A review of comparatively recent cases indicates that the old doctrine of equivalent of cash is outmoded and that an entirely new orientation of this concept is required. One Court has said that in this day and age income is not restricted to the receipt of tangibles where there is an actual recognizable benefit, albeit intangible, the taxation of which is implicit in the statutory scheme, and where such benefit is clearly capable of being evaluated

missioner, 20 T.C.M. (CCH) 1134, 1135 (1961). In reversing the original tax court decision, the court of appeals indicated that the case might have been affirmed were it not for the apparently determinative emphasis given by the tax court to the voluntary nature of the deferral. $280 \mathrm{~F} .2 \mathrm{~d}$ at 23-25. The court of appeals otherwise had no problem with the case as an application of the cash equivalence doctrine since it noted in dictum "the principle that negotiability is not the test of taxability ...."Id. at 24. Accordingly, on remand the tax court affirmed its earlier holding "without reference to the willingness and desire of (the payor) to pay the bonus payments in their entirety in a lump sum in 1951 ..." 20 T.C.M. (CCH) at 1135.

Note that the ultimate holding in Cowden turns largely on its facts. Other cases have distinguished Cowden. See, e.g., Leonard Hyatt, 20 T.C.M. (CCH) 1635 (1961), affd per curiam on other grounds, 325 F.2d 715 (5th Cir. 1963), cert. denied, 379 U.S. 832 (1964) (nonnegotiable but transferable contract not taxable to promisee where he did not believe the agreement had a fair market value and had no intention of marketing it). It should be noted, however, that the payor in Hyatt was inancially unsound.

156. 289 F.2d at 24 (dicta) (footnote omitted).

157. See Knight, supra note 62 , at 176.

158. I.R.C. $\$ 61(a)$.

159. Commissioner v. LoBue, 351 U.S. 243 (1956); Commissioner v. Glenshaw Glass Co., 348 U.S. 426 (1955); Commissioner v. Smith, 324 U.S. 177 (1945). 
on an objective basis. ${ }^{160}$

In the context of deferred compensation arrangements, the question is whether "any economic or financial benefit [was] conferred on the employee as compensation" in a given taxable year. ${ }^{161}$ It is specifically in the area of employee-compensation arrangements that the principle emerged that income may be realized although the property or evidence of property received is not transferable, provided that the right to such income is nonforfeitable. Although preceded by a number of closely parallel cases, ${ }^{162}$ the landmark decision in this area is United States v. Drescher. ${ }^{163}$

In Drescher, an employer purchased an annuity contract for a key employee, with the understanding that the employer would retain possession of the policy until the annuitant should reach the age of sixtyfive. The contract was nonassignable and had no cash surrender, sale or loan value. The court distinguished the nature of the arrangement from a mere promise to pay and characterized the problem confronting it as one of valuation rather than taxability. ${ }^{164}$ Since the taxpayer failed to establish the present value of the annuity, the court valued the policy on the basis of its cost and characterized that value as a taxable economic benefit, notwithstanding that the nontransferable annuity contract had no cash surrender or loan value. The court's reasoning is significant:

It cannot be doubted that in 1939 the plaintiff received as compensation for prior services something of economic benefit which he had not previously had, namely, the obligation of the insurance company to pay money in the future to him or his designated beneficiaries on the terms stated in the policy. That obligation he acquired in 1939 notwithstanding the employer's retention of possession of the policy and notwithstanding its nonassignability. ${ }^{165}$

160. 2 J. MERTENS, supra note $149, \S 11.02$.

161. J.H. McEwen, 6 T.C. 1018, 1026 (1946).

162. Hackett v. Commissioner, 159 F.2d 121 (1st Cir. 1946); Oberwinder v. Commissioner, 147 F.2d 255 (8th Cir. 1945); Renton K. Brodie, 1 T.C. 275 (1942).

163. 179 F.2d 863 (2d Cir. 1950).

164. Id at 866.

165. Id. at 865. While concurring in the result in Drescher, one member of the court dissented in part from the court's reasoning. Objecting to what he regarded as an unrealistic attempt to introduce valuation questions into the discussion of the proper tax treatment of the benefit conferred on the employee, Judge Clarke argued that

[i]n the light of the modern conditions of life, the satisfying of the highly natural and indeed burning desire of most men of middle age to obtain security for their old age and for their widows at death seems so clearly an economic benefit that I wonder it has been questioned so much as it has. Nor do I see the need to support this conclusion by looking for some highly theoretical possibility of turning this benefit into immediate dollars and cents. . . .

Hence unless these benefits are now taxed, this small group of top executives will be given a tax advantage not accruing to less fortunate or less well-advised persons. Such 
The principle established by Drescher has since been accepted universally by the courts ${ }^{166}$ and finds its parallel in section 403(c) of the Code, which conclusively measures income received by an employee on the basis of the amounts paid by the employer for the annuity in question. ${ }^{167}$

2. Applying the Economic Benefit Rule to Unfunded Deferred Compensation Arrangements. It has been established that the transferability of a promise to pay is not determinative of its taxability under the economic benefit doctrine. In the context of annuities, at least, the characterization turns instead on the abstract benefit of the economic security represented by the obligation of an insurance company to pay money to the taxpayer in the future. It is the position of this Comment that a similar abstract benefit accrues to an employee who receives an unfunded promise of future payment from a solvent employer. Support for this contention is found more readily by examining the practical realities of economic life than by analyzing legal abstractions.

In the context of the unfunded deferred compensation arrangement, taxing items of income only as they are actually received by the terms of the agreement is an artificial distortion of the taxpayer's income that does not adequately reflect his true annual compensation. Indeed, the calculated tax advantages incorporated into the taxpayer's nonforfeitable compensation arrangement, as currently permitted by law, may be among the most significant financial benefits comprising his current compensation. Certainly the arrangement is "valuable" to him. Indeed, it is generally regarded by employers as an important means of providing key employees with incentive. ${ }^{168}$ It can fairly be concluded that the employer's unfunded promise to pay money in the future should be taxable as a current economic benefit whenever the deferred income is nonforfeitable. Inasmuch as this operation of the economic benefit rule can be postponed by the inclusion of a forfeiture clause in the deferral contract, no undue hardship would be imposed

taxation should not be confused or rendered abortive by directions for valuation impossible of execution in any realistic way.

Id. at 867-69.

166. See Anastasio v. Commissioner, 67 T.C. 814 (1977); Charles Wilson, 39 T.C. 362 (1962). See generally Hyde v. Commissioner, 301 F.2d 279 (2d Cir. 1962); Commissioner v. Treganowan, 183 F.2d 288 (2d Cir. 1950), cert. denied, 340 U.S. 853 (1950); Sibla v. Commissioner, 68 T.C. 422 (1977); Paul L. Frost, 52 T.C. 89 (1969). In Hogan v. United States, 513 F.2d 170 (6th Cir.), cert. denied, 423 U.S. 836 (1975), the court noted that the "Ip]resent vesting of a right, even if its enjoyment is postponed to the happening of a future event, is an important aspect of gross income for income tax purposes." 513 F.2d at 174.

167. I.R.C. $\$ 403$ (c). See Charles Wilson, 39 T.C. 362 (1962). See also cases cited at note 166 supra.

168. See note 3 supra and accompanying text. 
on those for whom the nonqualified deferred compensation arrangement is an important ingredient of an attractive compensation package.

Generally, cash method taxpayers report income for the year in which it is actually received and not for the year in which the right to receive it merely accrues. ${ }^{169}$ Thus, it might be argued that to characterize as an economic benefit an employer's mere promise to pay effectively places a cash method taxpayer on an accrual basis with regard to the earnings in question. However, the characterization of the fixed right to future payments as a currently taxable economic benefit presumes that the taxpayer has realized the face amount of the deferred obligation just as if he had received it. Thus, the proposed change arguably would be consistent with the cash method of accounting. Moreover, since the cash basis realization requirement is ultimately "founded on administrative convenience,"170 no great injustice would be committed by positing this result for the limited purpose of dealing effectively with nonqualified deferred compensation arrangements. Of course, this argument does not change the fact that, as a practical matter, the result reached with respect to the cash basis taxpayer would not differ from the result that would be reached were he on the accrual basis. Thus, the objection may be validly raised that the taxpayer's method of accounting would, indeed, be violated. However, that objection collapses in light of the language of section 446, which provides:

(a) GeNeral RULE.-Taxable income shall be computed under the method of accounting on the basis of which the taxpayer regularly computes his income in keeping his books.

(b) EXCEPTIONS.-If no method of accounting has been regularly used by the taxpayer, or if the method used does not clearly reflect income, the computation of taxable income shall be made under such method as, in the opinion of the Secretary, does clearly reflect income. ${ }^{171}$

Thus, it is evident that there is nothing particularly inviolate about a taxpayer's usual method of accounting.

Since the central concern should be to structure the tax consequences of nonqualified deferred compensation arrangements so as to serve the policy objectives operative in the area, the language of section 446 indicates, if anything, that the result postulated here is the correct one. Arguably, the cash method does not suitably account for income deferred by the terms of an employment contract because it does not take into account economic benefits conferred as well as cash received. It therefore should be replaced by another method capable of a realistic

169. Treas. Reg. $\$ \S 1.446-1$ (c)(1) (1973), 1.451-1(a) (1971).

170. Helvering v. Horst, 311 U.S. 112, 116 (1940).

171. I.R.C. \& 446(a), (b) (emphasis added). 
appraisal of annual income.

The concrete differences between funded and unfunded deferred compensation arrangements have not been ignored. To be sure, in the former case, funds are set aside for the employee's exclusive benefit, while in the latter case the employee stands as a general creditor of the corporation. Nor may it be said that these differences have never worked injury on the employee who satisfies himself with his employer's unsecured promise to pay. ${ }^{172}$ Nonetheless, it is suggested that the similarities between funded and unfunded plans outweigh the differences. Indeed, it is rare that one arrangement will ultimately prove more or less valuable to an employee than would the other, since the risks that attach with respect to the unfunded plan are remote. The subsequent insolvency of a corporate employer-obligor is the exception and not the rule. Finally, to whatever extent differences between funded and unfunded arrangements exist in fact, as a matter of policy these differences should be given less weight than the overall purposes of tax fairness.

\section{CONCLUSION}

It is by now well established that "[a]ny one may so arrange his affairs that his taxes shall be as low as possible; he is not bound to choose that pattern which will best pay the Treasury; there is not even a patriotic duty to increase one's taxes."173 Thus, to the extent that a method of tax avoidance is permitted, it can and will be utilized. Often matters must get out of hand before the need for change becomes apparent. Such were the circumstances that gave rise to Proposed Regulation section 1.61-16.

The laissez-faire policy of Revenue Ruling 60-31, which provides almost unlimited freedom in the use of unfunded nonqualified deferred compensation arrangements, should not be permitted to go unchallenged. Therefore, now that the most recent challenge has been effectively defeated, some alternative basis for change in the area of nonqualified deferred compensation arrangements should be formulated and implemented. The Proposed Regulation would have limited strictly the availability of unfunded nonqualified plans to the relatively few instances where they are required by employers for business reasons. Admittedly, the proposal advanced by this Comment falls short

172. See In re Penn Central Transp. Co., 484 F.2d 1300 (3d Cir.), cert. denied, 415 U.S. 951 (1973); Alpert v. New York, N.H. \& H. R.R., 348 F.2d 304 (2d Cir. 1965) (executives' claims under unfunded deferred compensation plans given no preference under provisions of the Bankruptcy Act so that the basis of recovery of claims must be that afforded general creditors of bankrupt).

173. Gregory v. Helvering, 69 F.2d 809, 810 (2d Cir. 1934), aff'd, 293 U.S. 465 (1935). 
of accomplishing any such sweeping and direct change. Nonetheless, it is a step in the direction of implementing tax policy objectives.

Longstanding policy objectives of a fundamental kind-for example, that wealth be redistributed in accordance with the general scheme of the present graduated tax system - are only partially implemented so long as the law affords tax benefits to arrangements which defeat those objectives. This is especially problematical if tax policy is to reflect, as it should, the collective sense of justice of the American people. The desire to provide equally for the basic needs of all American citizens operates to disfavor elitist tax advantages and to buttress the demand for a properly functioning progressive tax structure. Although current law covering nonqualified deferred compensation plans undoubtedly plays only a relatively small part in the erosion of the tax structure, it nonetheless is a problem that can and should be corrected. Deferred compensation arrangements are, after all, supposed to serve as a means of retirement planning. It is no part of policy that they be permitted-and even encouraged-to serve the goals of tax avoidance.

Thomas W. Giegerich 